\title{
PELATIHAN PENGELOLAAN SAMPAH ORGANIK IBU-IBU PKK DI PERUMAHAN RENY JAYA RT 04 RW 07 KELURAHAN PONDOK PETIR KECAMATAN BOJONG SARI DEPOK
}

\author{
Sandra Madonna ${ }^{1}$, Prismita Nursetyowati ${ }^{2}$, Hermiyetti $^{3}$ \\ 12 Program Studi Teknik Lingkungan, ${ }^{3}$ Program Studi Akuntansi, Universitas Bakrie, Jakarta, 12960, \\ Indonesia \\ E-mail: ${ }^{1}$ sandra.madonna@bakrie.ac.id*, ${ }^{2}$ prismita.nursetyowati@bakrie.ac.id, ${ }^{3}$ hermiyetti@bakrie.ac.id \\ DOI: https://doi.org/10.36782/ijsr.v1i02.11
}

\begin{abstract}
Abstrak
Kelurahan Pondok Petir merupakan kelurahan dengan jumlah penduduk paling besar di Kecamatan Bojongsari, Depok. Perumahan Reny Jaya salah satu perumahan terbesar di Pondok Petir. Besarnya jumlah penduduk dan keanekaragaman aktivitas ini berkontribusi terhadap peningkatan jumlah dan permasalahan sampah. Sampah organik yang berasal dari rumah tangga mendominasi timbulan sampah di Indonesia. Timbulan sampah organik di Kelurahan Pondok Petir berpotensi untuk dikelola dengan baik. Metode komposting menggunakan keranjang Takakura dan pengolahan minyak jelantah menjadi sabun sangat tepat diperkenalkan sebagai teknologi tepat guna dalam pengolahan sampah organik yang berasal dari rumah tangga. Permasalahan yang terjadi saat ini adalah partisipasi masyarakat yang masih kurang terarah dan terorganisir secara baik, masih minimnya kepedulian masyarakat terhadap permasalahan sampah. Adanya potensi sampah rumah tangga untuk diolah bahkan dapat bernilai ekonomi, namun belum maksimal diterapkan karena masih kurangnya motivasi dan wawasan masyarakat dalam mengelola sampah. Kegiatan Pelatihan Pengelolaan Sampah telah dilakukan, dihadiri oleh 16 orang peserta yang terdiri dari ibu-ibu rumah tangga di RT 04 RW 07 Kelurahan Pondok Petir, Depok. Dengan metode penyampaian secara presentasi, praktik pembuatan komposter Takakura, pembuatan sabun cuci dari minyak jelantah, serta diskusi dan tanya jawab. Pelatihan pengolahan sampah skala rumah tangga ini diharapkan dapat meningkatkan keterlibatan masyarakat di Kelurahan Pondok Petir dalam mengelola sampah mereka, dan dapat mensosialisasikan serta memotivasi rumah tangga lain di sekitar sehingga dapat menjadi salah satu contoh kawasan yang bersih, sehat, dan bebas dari sampah.
\end{abstract}

Kata Kunci: Kelurahan Pondok Petir, keranjang Takakura, minyak jelantah, sampah organik, sampah rumah tangga

\section{Abstract}

Pondok Petir Village is the largest population in Bojongsari Subdistrict, Depok. The biggest land use in this Kelurahan is for housing. Reny Jaya Housing is one of the largest housing estates in Pondok Petir. The large population and diversity of these activities contribute to increasing the number and problem of waste. Organic waste originating from households dominates waste generation in Indonesia. The accumulation of organic waste in Pondok Petir Kelurahan has the potential to be managed better. Composting method using Takakura basket and processing used cooking oil into soap are very appropriate to be 
introduced as an appropriate technology to treat organic waste from households. The problem that is happening currently is that community participation is still not welldirected and well-organized, there is still a lack of community sanctity towards the waste problem. The household waste has a potential to be processed as something valuable, but it has not been maximally implemented because there is still a lack of motivation and insight from the community in managing waste. The Waste Management Training Activity has been carried out, attended by 16 participants consisting of housewives in RT 04 RW 07 Kelurahan Pondok Petir, Depok. The making Takakura composter and making washing soap from used cooking oil were explained with presentation followed by practice as well as discussion. This household scale waste management training is expected to increase community involvement in the Pondok Petir Kelurahan in managing their waste, and can socialize and motivate other households in the vicinity so that it can become one of the examples of areas that are clean, healthy, and free of untreated waste.

Keywords: Pondok Petir Village, Takakura basket, used cooking oil, organic waste, household organic waste

\section{Latar Belakang}

Manajemen sampah kota di negara dengan pendapatan per kapita rendah dan sedang adalah permasalahan yang masih sangat menantang dan seringkali belum menjadi prioritas utama (Diener dkk, 2011). Sampah kota biasanya diklasifikasikan menurut tingkat biodegradability-nya, yaitu sampah organik dan sampah non-organik. Biasanya di banyak negara, sampah organik memiliki volume yang jauh lebih besar dibanding sampah non-organik. Sampah organik, apabila volumenya sangat besar ini tidak tertangani dengan baik, ini akan memperburuk kualitas air, udara dan tanah dan sangat berpengaruh pada persediaan makanan, energi dan air (Lin dkk, 2018).

Selain itu, keberadaan sampah organik di Tempat Pembuangan Akhir (TPA) berkontribusi melepaskan gas metan sehingga berpengaruh meningkatkan gas rumah kaca (Couth dkk, 2009). Oleh karena itu, sudah banyak negara di dunia yang berusaha mengurangi kuantitas sampah organik dengan berbagai strategi.

Di Jepang, walau sebagian besar sampah kota dimusnahkan dengan insinerasi, ada usaha untuk mengurangi kuantitas sampah organik ke dalam insinerasi. Diharapkan langkah tersebut dapat mengurangi emisi dioksin. Begitu juga di negara-negara Eropa dan Korea, sudah ada langkah administratif untuk mengurangi kuantitas sampah organik di TPA walau teknologi insinerasi belum terlalu diperkenalkan. Oleh karena itu, saat ini pengolahan sampah organik dengan komposting menjadi strategi yang sangat penting untuk mengurangi kuantitas sampah organik ke TPA dan insinerator (Sakai dkk, 2011)

Komposting adalah metode yang menguntungkan untuk menggunakan kembali (recycling) sampah organik menjadi pupuk (Nakasaki dkk, 2019). Sudah banyak negara yang menerapkan komposting sebagai alternatif untuk pengolahan sampah organik. Di India, pemerintahnya mencanangkan inisiatif pengolahan utama sampah kota dengan komposting. Saat ini, sekitar 9\% sampah organiknya diproses dengan komposting (Sharholy dkk, 2008). Di Pudong, Cina, sampah organik juga sebagian besar dikompos, melebihi yang masuk ke TPA (Minghua, 2009).

Di Indonesia sendiri, sebagai negara berkembang, produksi timbulan sampahnya meningkat seiring dengan perkembangan populasi yaitu mencapai $190.000 \mathrm{mton} / \mathrm{hari}$ di tahun 2014 (Sudibyo dkk, 2017). Pengelolaan sampah di Indonesia diatur dalam Undang Undang No. 18 Tahun 2008 yang secara komprehensif mengatur segala 
aspek di dalam pengelolaan sampah terutama sampah kota di Indonesia. Akan tetapi dalam aplikasinya, penegakan hukum dan kesadaran masyarakat yang rendah salah satunya menyebabkan implementasi pengelolaan sampah di Indonesia masih kurang baik (Meidiana dkk, 2011), yaitu masih dalam lingkup kumpul-angkut-buang ke TPA termasuk di ibukota Jakarta (Pasang dkk, 2007), Padang (Raharjo dkk, 2015) dan kota-kota lain di Indonesia.

Sudah banyak usaha mengelola sampah dengan prinsip 3R (Reduce-Reuse-Recycle) yang di dalamnya terdapat komposting sebagai salah satu contoh prinsip recycle, baik dari pemerintah ataupun komunitas. Konsep ini apabila dijalankan dengan baik dapat mengurangi sampai $67 \%$ dari sampah seperti yang dilakukan Trihadiningrum dkk (2015) di Surabaya. Akan tetapi, program 3R susah beroperasi secara berkelanjutan karena kurangnya komitmen pemerintah dalam menjalankan program yang telah dibuat, kurangnya koordinasi antar pihak yang berhubungan dengan sistem pengelolaan sampah dan kesadaran masyarakat yang rendah (Pasang dkk, 2007).

Program 3R ini dapat berjalan apabila ada kesadaran dari masyarakatnya sendiri (41\%), ajakan dari ketua komunitas sekitar (30\%) dan efek dari pelatihan (11\%) (Trihadiningrum dkk, 2015). Di studi ini terlihat bahwa peningkatan kesadaran masyarakat mengenai pengelolaan sampah dengan melakukan pelatihan $3 R$ dapat menjadi salah satu cara yang sangat efektif. Oleh karena itu, Universitas Bakrie mempunyai kepedulian untuk melakukan kegiatan pengabdian masyarakat: "Pelatihan Pengelolaan Sampah Organik Ibu-Ibu PKK di $\begin{array}{lllll}\text { Perumahan Reny Jaya RT } 04 & \text { RW } & 07\end{array}$ Kelurahan Pondok Petir Kecamatan Bojong Sari Depok".

Kelurahan Pondok Petir merupakan kelurahan yang memiliki jumlah penduduk paling besar di Kecamatan Bojongsari, Kota Depok (Kecamatan Bojongsari dalam Angka, 2018). Selain itu, penggunaan lahan terbesar di Kelurahan Pondok Petir ini adalah untuk perumahan, sehingga pengabdian masyarakat ini mengambil lokasi di Perumahan Reny Jaya sebagai salah satu perumahan terbesar di Kecamatan Bojongsari. Besarnya jumlah penduduk dan keanekaragaman aktivitas di Kelurahan Pondok Petir berkontribusi terhadap peningkatan jumlah dan permasalahan dari timbulan sampah. Selain itu, kegiatan pengabdian masyarakat ini dapat juga mendukung Program Kampung Iklim (ProKlim) yang sedang gencar diterapkan d cara merata di Kota Depok melalui Dinas Lingkungan Hidup dan Kebersihan (DLHK) Kota Depok (Adreena, 2019).

Program Kampung Iklim (ProKlim) adalah program berlingkup nasional yang dikembangkan Kementerian Lingkungan Hidup (KLH) untuk mendorong partisipasi aktif masyarakat dan seluruh pihak dalam melaksanakan aksi lokal untuk meningkatkan ketahanan terhadap dampak perubahan iklim dan pengurangan emisi Gas Rumah Kaca (GRK) (Kementerian Lingkungan Hidup dan Kehutanan).

Kegiatan pengabdian masyarakat yang telah dilakukan menggunakan dua aspek pendekatan yaitu pertama pendekatan secara teknologi dengan melakukan pelatihan pengolahan sampah rumah tangga dan yang kedua pendekatan secara sosial dengan melakukan sosialisasi pengelolaan sampah rumah tangga kepada masyarakat khususnya kepada ibu-ibu rumah tangga yang pada kenyataannya secara langsung terlibat dalam penanganan sampah di rumah tangga.

\section{Tinjauan Kebijakan dan Pustaka}

\section{A. Pengelolaan Sampah Kota dengan 3R}

Menurut Fariatamby dan Fauziah (2014), hirarki pengelolaan sampah kota yang berkelanjutan tergambar dalam Gambar 2.1. Terlihat perbedaannya dengan hirarki pengelolaan sampah yang lama, yang mana aspek 3R menjadi aspek utama yang lebih dipilih untuk mengelola sampah kota. 


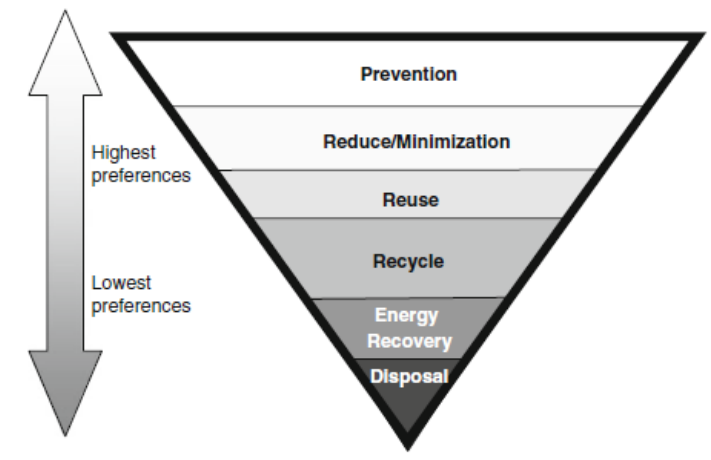

Gambar 1. Hirarki Pengelolaan Sampah Kota (Sumber: Fariatamby dan Fauziah, 2014)

Menurut Fariatamby dan Fauziah (2014), dalam pelaksanaan 3R banyak faktor yang berpengaruh pada keberhasilannya yaitu faktor ekonomi, sumber daya manusia, institusi dan lingkungan (Gambar 2.2). Semua faktor tersebut harus menjadi pertimbangan matang agar proses $3 R$ berkelanjutan.

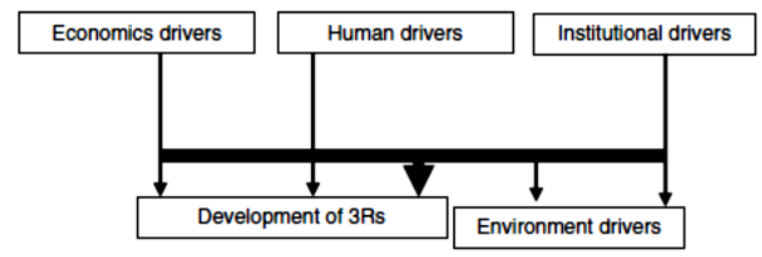

Gambar 2. Perkembangan 3R

(Sumber: Fariatamby dan Fauziah, 2014)

\section{B. Pengolahan Sampah Organik dengan Takakura}

Salah satu cara mengolah sampah organik menjadi kompos adalah dengan menggunakan keranjang Takakura atau Takakura Home Method (Cintawati dan Handojo, 2014). Metode komposting skala rumah tangga ini dikembangkan oleh Institute for Global Environmental Strategies (IGES) Jepang (Jiménez-Antillón dkk, 2018).

Struktur Keranjang Takakura disajikan pada Gambar 2.3. Sistem Takakura ini didesain untuk beroperasi pada tempat yang kecil seperti dapur dan halaman sehingga sangat ideal untuk rumah tangga (Kurniawan dkk, 2013). Pada penelitian yang dilakukan oleh Jiménez-Antillón dkk (2018), substrat pencampur kompos yang digunakan adalah campuran dari dua larutan, yaitu larutan manis (campuran gula dan ragi) dan larutan asin (campuran garam dan sayuran). Setiap Keranjang Takakura didesain dengan ukuran $33 \mathrm{~cm} \times 50 \mathrm{~cm} \times 30 \mathrm{~cm}$ dan total area 0.16 m2. Keranjang Takakura diisi sampah makanan kira-kira 1,2 kg per hari.

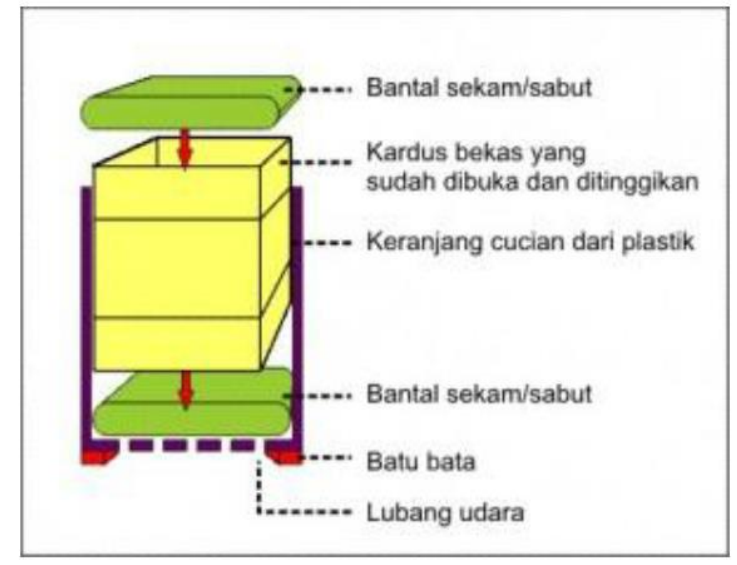

Gambar 3. Struktur Keranjang Takakura (Sumber: Ghufron dkk., 2017)

Menurut Rezagama dan Samudro (2015), metode pengomposan Keranjang Takakura memiliki keunggulan dibandingkan dengan metode lain:

1. Praktis, karena sangat cocok untuk perumahan dengan lahan yang tidak begitu lebar. Keranjang dapat ditempatkan di mana saja sesuai dengan kebutuhan dan ketersediaan lahan.

2. Mudah, karena sampah hanya dimasukkan, setiap harinya. Tanpa ada perlakukan khusus seperti menambahkan cairan atau bahan-bahan tambahan yang lain.

3. Tidak berbau, karena prosesnya melalui proses fermentasi, bukan pembusukan.

\section{Pemanfaatan Minyak Jelantah menjadi Sabun}

Minyak jelantah merupakan minyak sisa-sisa pengorengan yang tidak bisa digunakan kembali, sehingga biasanya dibuang begitu saja ke saluran pembuangan. Limbah yang terbuang ke pipa dapat menyumbat pipa pembuangan karena pada suhu rendah minyak akan membeku dan menggangu jalannya air pada saluran pembuangan (Wijaya dkk, 2014). Minyak goreng bekas (jelantah) ini apabila 
dikonsumsi dapat mengganggu kesehatan (Pratiwi, 2014). Salah satu potensi limbah minyak goreng adalah kandungan asam lemak yang tinggi sehingga dapat dimanfaatkan menjadi sabun cuci piring yang ramah lingkungan (Kusumaningtyas dkk, 2018).

Sabun merupakan senyawa natrium atau kalium dengan asam lemak dari minyak nabati atau lemak hewani berbentuk padat, lunak atau cair dan berbusa. Sabun dihasilkan dari proses saponifikasi yaitu hidrolisis lemak menjadi asam lemak dan gliserol dalam kondisi basa. Pembuatan kondisi basa yang biasa digunakan adalah Natrium Hidroksida ( $\mathrm{NaOH})$ dan Kalium Hidroksida (KOH). Jika basa yang digunakan adalah $\mathrm{NaOH}$, maka produk yang dihasilkan berupa sabun padat, sedangkan jika basa yang digunakan berupa $\mathrm{KOH}$ maka produk yang dihasilkan berupa sabun cair (Sukeksi dkk., 2017).

Menurut Kusumaningtyas dkk (2018), tahapan pembuatan sabun dari minyak jelantah adalah sebagai berikut.

1. Tahap pemurnian minyak goreng melalui proses penghilangan bumbu (despicing) minyak goreng bekas (jelantah).

2. Tahap netralisasi

3. Tahap pemucatan (bleaching) dengan karbon aktif

4. Tahap pembuatan sabun cuci piring. Campuran $\mathrm{KOH}$ dan minyak jelantah diaduk dengan mixer selama 45 menit. Untuk memberikan aroma dan warna yang menarik, parfum dan pewarna makanan ditambahkan, bisa juga dengan pewarna alami seperti pandan.

\section{Pembahasan}

Hasil kegiatan Pengabdian masyarakat ini adalah Mitra kegiatan PKM dalam hal ini ibu-ibu Pemberdayaan Kesejahteraan Keluarga (PKK) di Perumahan Reny Jaya RT 04 RW 07 Kelurahan Pondok Petir Kecamatan Bojong Sari Depok mampu membuat kompos sendiri di rumah masingmasing dengan keranjang Takakura yang telah bagikan pada saat acara pelatihan
Pengelolaan Sampah Organik oleh tim PKM. Teknik pengelohan sampah organik atau sampah dapur dengan metode Takakura dengan mudah dipahami dan diterapkan oleh mitra karena praktis, mudah, tidak berbau dan ramah lingkungan seperti yang dikemukakan Rezagama dan Samudro pada Studi Optimasi Takakura dengan Penambahan Sekam dan Bekatul (2015).

Kelurahan Pondok Petir Kecamatan Bojong Sari Depok dipilih sebagai lokasi kegiatan karena termasuk lokasi yang padat penduduk, dalam hal ini RT 04 RW 07 yang terdiri dari 37 Kepala keluarga. Perumahan komplek di lokasi PKM ini sudah cukup teratur, namun untuk pengelolaan sampahnya masih secara kumpul angkut buang belum ada upaya untuk melaksanakan 3R mulai dari sumber timbulan yaitu mulai dari rumah-rumah penduduk yang seharusnya dapat dilakukan. Minimnya informasi dan kepedulian masyarakat terhadap sampah ini bisa menjadi penyebab kurang optimalnya pengelolaan sampah di lokasi ini.

Menurut Tchobanoglous G., (1993), pengenalan konsep pengurangan sampah melalui konsep 3R (Reduce (pembatasan), Reuse (daur guna), Recycling (daur ulang)) dan pengenalan teknologi tepat guna dalam pengolahan sampah kepada masyarakat dapat mengedukasi dan menambah wawasan dan minat masyarakat dalam mengelola sendiri limbahnya/sampah. Pengenalan cara-cara sederhana dan aplikatif sangat diperlukan sehingga masyarakat dapat menerapkan secara langsung di lingkungannya

Disamping memperkenalkan Metode Takakura sebagai solusi pengolahan sampah organik rumah tangga atau sampah dapur, dalam kegiatan PKM ini juga dilakukan pelatihan membuat sabun yang berasal dari minyak jelantah atau minyak sisa pengorengan dari dapur. Selain sisa-sisa sayuran dan buah-buahan minyak jelantah pun merupakan limbah organik yang berasal dari dapur yang berpotensi untuk diolah mulai dari rumah tangga. 
Kusumaningtyas dkk. (2018), mengemukakan bahwa salah satu potensi limbah minyak goreng adalah kandungan asam lemak yang tinggi sehingga dapat dimanfaatkan menjadi sabun cuci piring yang ramah lingkungan. Pada akhir kegiatan pelatihan ini Ibu-Ibu PKK di Perumahan Reny Jaya pun berhasil membuat sabun cuci yang bisa mereka bawa pulang untuk digunakan dalam mencuci.

Dari Kegiatan Pelatihan Pengelolaan Sampah Organik Ibu-Ibu PKK di Perumahan Reny Jaya RT 04 RW 07 Kelurahan Pondok Petir Kecamatan Bojong Sari Depok dapat dianalisis bahwa telah terpecahkannya masalah persampahan di Perumahan Reny Jaya Depok khususnya masalah sampah dapur atau sampah organik dengan memperkenalkan metoda pengolahan sampah rumah tangga yang sederhana menggunakan keranjang Takakura dan pengolahan minyak goreng bekas kepada warga sekitar, dan disertai dengan pembagian komposter sederhana berupa keranjang sampah Takakura, dan sabun hasil pelatihan kepada masing-masing peserta. Terwujudnya lingkungan sekitar Perumahan Reny Jaya RT 04 RW 07 Depok yang bersih dan nyaman dengan telah dilakukan pengolahan sampah mulai dari rumah tangga.

Pada kegiatan presentasi dan perlatihan terlihat antusias yang tinggi pada peserta untuk mendapatkan informasi dan pengetahuan mengenai cara-cara penanganan sampah yang baik dan efisien terlihat dari jumlah peserta yang hadir dan antusiasme peserta untuk bertanya pada saat presentasi serta diskusi tanya jawab. Dari pertanyaan peserta pelatihan terlihat kesadaran masyarak untuk mengelola sampahnya sendiri, terlihat pula meningkatnya minat masyarakat memanfaatkan sampah dapur mereka untuk membuat kompos dan mengolah minyak goreng bekas pakainya menjadi sabun cuci.

Pada kegiatan ini pun telah terjadi penyebarluasan informasi mengenai pelestarian lingkungan, pentingnya mengelola sampah mulai dari rumah tangga, dan cara mengolah sampah rumah tangga program ini yang dibuktikan dengan terlaksananya pembuatan komposter sederhana dan pemanfaatan minyak goreng bekas pakai oleh setiap peserta pelatihan yang akan diaplikasikan di rumahnya masing-masing, bahkan sebagian dari peserta akan membagikan ilmu dan pengetahuan yang didapat dari pelatihan ke tetangga atau ibu-ibu rumah tangga sekitar yang belum sempat mengikuti pelatihan ini.

Kegiatan Pelatihan Pengelolaan Sampah Organik Ibu-lbu PKK di Perumahan Reny Jaya RT 04 RW 07 Kelurahan Pondok Petir Kecamatan Bojong Sari Depok, merupakan kegiatan bersifat social engineering yang mengajarkan masyarakat untuk memilah sampah, mengolah sampah serta menumbuhkan kesadaran masyarakat dalam pengelolaan sampah secara bijak, harus terus dilakukan dengan inovasi terus menerus sehingga akhirnya diharapkan akan mengurangi sampah yang akan diangkut ke TPA.

\section{Kesimpulan}

Dari kegiatan ini dapat disimpulkan bahwa masyarakat mengetahui bagaimana mengelola sampah mereka mulai dari rumah tangga. Teknologi tepat guna dalam pengolahan sampah organik berhasil diperkenalkan. Masyarakat berhasil membuat komposter sederhana dengan metoda Takakura dan membuat sabun cuci dari sampah dari dapur mereka masingmasing. Sehingga terbentuknya keterlibatan masyarakat dalam usaha pelestarian lingkungan dan terwujudnya lingkungan Perumahan Reny Jaya RT 04 RW 07 Kelurahan Pondok Petir Kecamatan Bojong Sari Depok yang sehat, bersih dan nyaman yang bebas dari sampah.

\section{Ucapan Terima Kasih}

Terima kasih kepada Lembaga Pengabdian Masyarakat Universitas Bakrie, yang telah mendanai dan memfasilitasi untuk kegiatan PkM ini. 


\section{Daftar Pustaka}

Adreena. 2019. Dukung Program Proklim, Pemkot Gencar Lakukan Pemerataan Kampung Iklim [Internet]. [Diakses pada 22 Juli 2019]. Tersedia pada: https://godepok.com/dukung-programproklim-pemkot-gencar-lakukanpemerataan-kampung-iklim/

BPS Kota Depok. 2018. Kecamatan Bojongsari dalam angka [Internet]. [22 Juli 2019]. Tersedia pada: https://depokkota.bps.go.id/publication /2018/09/26/f0f1665dc43f98c8eb790ac 5/kecamatan-bojongsari-dalam-angka2018.html

Couth, R., Trois, C. 2009. Comparison of waste management activities across Africa with respect to carbon emissions. The 12th International Waste Management and Landfill Symposium Italy 2009.

Diener, S., Solano, S.N.M., Roa Gutiérrez, F., Zurbrügg, C., Tockner, K. 2011. Biological Treatment of Municipal Organic Waste Using Black Soldier Fly Larvae. Waste and Biomass Valorization, 2(4): 357-363.

Ghufron, M.A., Rozak, R.R., Fitrianingsih, A., Matin, M.F., Amin, A.K. 2017. Pelatihan Pengolahan Sampah Organik Menjadi Kompos dengan Media Keranjang Takakura. Jurnal Pengabdian Kepada Masyarakat, 1(1): 98-108.

Jiménez-Antillón, J., Calleja-Amador, C., Romero-Esquivel, L.G. 2018. Food Waste Recovery with Takakura Portable Compost Boxes in Offices and Working Places. Resources, 7(84): 1-13.

Kementerian Lingkungan Hidup dan Kehutanan. Program Kampung Iklim (Proklim) [Internet]. [Diakses 22 Juli 2019]. Tersedia pada: http://proklim. menlhk.go.id

Kurniawan, T.A., Puppim De Oliveira, J., Premakumara, D.G.J., Nagaishi, M. 2013. City-to-city level cooperation for generating urban co-benefits: The case of technological cooperation in the waste sector between Surabaya
(Indonesia) and Kitakyushu (Japan). Journal of Cleaner Production, 58: 4350.

Kusumaningtyas, R.D., Qudus, N., Putri, R.D.A., Kusumawardani, R. 2018. Penerapan Teknologi Pengolahan Limbah Minyak Goreng Bekas Menjadi Sabun Cuci Piring untuk Pengendalian Pencemaran dan Pemberdayaan Masyarakat. Abdimas, 22(2): 201-208.

Lin, L., Xu, F., Ge, X., Li, Y. 2018. Improving The Sustainability of Organic Waste Management Practices in The FoodEnergy-Water Nexus: A Comparative Review Of Anaerobic Digestion and Composting. Renewable and Sustainable Energy Reviews, 89: 151-167.

Meidiana, C. dan T. Gamse. 2010. Development of Waste Management Practices in Indonesia. European Journal of Scientific Research, 40(2): 199-210.

Minghua, Z., Xiumin, F., Rovetta, A., Qichang, H., Vicentini, F., Bingkai, L. 2009. Municipal Solid Waste Management in Pudong New Area, China. Waste Management, 29: 1227-1233.

Nakasaki, K., Hirai, H., Mimoto, H., Quyen,

T.N.M., Koyama, M., Takeda, M. 2019. Succession of Microbial Community During Vigorous Organic Matter Degradation in The Primary Fermentation Stage of Food Waste Composting. Science of The Total Environment, 671: 1237-1244.

Pasang, H., Moore, G.A., Sitorus, G. 2007. Neighbourhood-Based Waste Management: A Solution for Solid Waste Problems in Jakarta, Indonesia. Waste Management, 27: 1924-1938.

Pariatamby, A. dan M. Tanaka (Eds.). 2014. Municipal solid waste management in Asia and the Pacific Islands, Environmental Science and Engineering. Singapore: Springer-Verlag.

Pratiwi, P. 2014. Pembuatan Sabun Cuci Piring Cair dari Minyak Goreng Bekas (Jelantah). Tugas Akhir Universitas Sebelas Maret. 
Raharjo, S., Matsumoto, T., Ihsan, T., Rachman, I., Gustin, L. 2017. Community-Based Solid Waste Bank Program for Municipal Solid Waste Management Improvement in Indonesia: A Case Study Of Padang City. Journal of Material Cycles and Waste Management, 19(1): 201-212.

Rezagama, A., Samudro, G. 2015. Studi Optimasi Takakura dengan Penambahan Sekam dan Bekatul. Jurnal Presipitasi, 12 (2): 66-70.

Sakai, S., Yoshida, H., Hirai, Y., Asari, M., Takigami, H., Takahashi, S., Tomoda, K., Peeler, M.V., Wejchert, H., SchmidUnterseh, T., Douvan, A.R., Hathaway, R., Hylander, L.D., Fischer, C., Oh, G.J., Jihui, L., Chi, N.K. 2011. International Comparative Study of $3 R$ and Waste Management Policy Developments. Journal of Material Cycles and Waste Management, 13(2): 86-102.

Sharholy, M., Ahmad, K., Mahmood, G., Trivedi, R.C. 2008. Municipal Solid Waste Management In Indian Cities - A Review. Waste Management, 28: 459467.
Sudibyo, H., Majid, A.I., Pradana, Y.S., Budhijantoa, W., Deendarlianto, Budimana, A. 2017. Technological Evaluation of Municipal Solid Waste Management System in Indonesia. Energy Procedia, 105: 263 - 269.

Sukeksi, L., Sidabutar, A. J., Sitorus. C. 2017. Pembuatan Sabun Dengan Menggunakan Kulit Buah Kapuk (Ceiba petandra) Sebagai Sumber Alkali. Jurnal Teknik Kimia USU, 6(3): 8-13.

Trihadiningrum, Y., Laksono, I.J., Dhokhikah, Y., Moesriati, A., Radita, D.R., Sunaryo, S. 2017. Community Activities in Residential Solid Waste Reduction in Tenggilis Mejoyo District, Surabaya City, Indonesia. Journal of Material Cycles and Waste Management, 19(1): 526535.

Wijaya, J., Rohanah, A., Rindang, A. 2014. Pengolahan Minyak Jelantah menjadi Sabun Batang dengan Ekstrak Kunyit, Lidah Buaya, Dan Papaya. Jurnal Rekayasa Pangan dan Pertanian, 2(4): 139-145. 